\title{
Comparative Study of Synthesis, Structural and Antioxidant Activity In Vitro of Some New Carboxylic $\alpha, \alpha$-diaminodiesters Derivatives
}

Oumaima Karai, Sara Hajib, Serigne Abdou Khadir Fall, Salaheddine Boukhssas, Khadim Dioukhane, Younas Aouine, Brahim Labriti, Hassane Faraj, and Anouar Alami

\section{ABSTRACT}

Considering the richness of heterocyclic chemistry, and the diversity of applications it possesses, in the present work we were interested in preparing new polyfunctional $\alpha, \alpha$-diaminodiesters derived from glycine, via the $\mathrm{N}$-alkylation reaction of methyl 2 -azido-2-benzamidoacetate with a series of heterocyclic and non-heterocyclic carboxylic aminoesters, using different bases. The structures of the synthesized molecules were characterized by 1D and 2D NMR spectroscopy, mass spectrometry (MSESI) and elemental analysis. Two compounds from this series were isolated as single crystals and their chemical structures were determined by X-ray diffraction. The antioxidant effect of the synthesized compounds was tested in vitro using the free radical scavenging power (DPPH) and reducing power (FRAP) tests. The results show that the different extracts tested have a relatively high antioxidant power compared to the positive control considered, especially for the compound methyl 2-benzamido-2(2-methoxy-2-oxo-1-phenylethyl)amino)acetate, which showed a very strong antiradical power and reducing power.

Keywords: $\mathrm{N}$-alkylation, $\alpha, \alpha$-diaminodiesters, antioxidant activity, DPPH, FRAP.
Published Online: July 13, 2021

ISSN: $2684-4478$

DOI : 10.24018/ejchem.2021.2.3.64

\section{Oumaima Karai}

Engineering Laboratory of Organometallic, Molecular Materials and Environment, Faculty of Sciences Dhar El Mahraz, Sidi Mohammed Ben Abdellah University, Fez, Morocco.

(e-mail: oumaima.karai@usmba.ac.ma) Sara Hajib

Engineering Laboratory of Organometallic, Molecular Materials and Environment, Faculty of Sciences Dhar El Mahraz, Sidi Mohammed Ben Abdellah University, Fez, Morocco.

(e-mail: sara.hajib@ ${ }^{@}$ usmba.ac.ma)

Serigne Abdou Khadir Fall

Engineering Laboratory of Organometallic,

Molecular Materials and Environment, Faculty of Sciences Dhar El Mahraz, Sidi Mohammed Ben Abdellah University, Fez Morocco.

(e-mail: serigneabdoukhadir.fall @ usmba.ac.ma) Salaheddine Boukhssas

Engineering Laboratory of Organometallic, Molecular Materials and Environment, Faculty of Sciences Dhar El Mahraz, Sidi Mohammed Ben Abdellah University, Fez, Morocco.

(e-mail: salaheddine.boukhssas ${ }^{\circledR}$ usmba.ac.ma) Khadim Dioukhane

Engineering Laboratory of Organometallic, Molecular Materials and Environment, Faculty of Sciences Dhar El Mahraz, Sidi Mohammed Ben Abdellah University, Fez, Morocco.

(e-mail: khadim.dioukhane ${ }^{@}$ usmba.ac.ma)

Younas Aouine

Team of Organic Chemistry and Valorization of Natural Substances, Faculty of Sciences, Ibn Zohr University, Agadir, Morocco.

(e-mail: y.aouine@uiz.ac.ma)

Brahim Labriti

Engineering Laboratory of Organometallic,

Molecular Materials and Environment, Faculty of Sciences Dhar El Mahraz, Sidi Mohammed Ben Abdellah University, Fez, Morocco.

(e-mail: Brahim.Labriti@ usmba.ac.ma) Hassane Faraj

Engineering Laboratory of Organometallic, Molecular Materials and Environment, Faculty of Sciences Dhar El Mahraz, Sidi Mohammed Ben Abdellah University, Fez, Morocco.

(e-mail: hassanefaraj@usmba.ac.ma)

Anouar Alami*

Engineering Laboratory of Organometallic, Molecular Materials and Environment, Faculty of Sciences Dhar El Mahraz, Sidi Mohammed Ben Abdellah University, Fez, Morocco.

(e-mail: anouar.alami@usmba.ac.ma)

*Corresponding Author 


\section{INTRODUCTION}

Organic chemistry has been evolving for more than two centuries. It continues to generate enormous scientific interest and economic imperatives. Therefore, heterocyclic $\alpha$-amino acids are of interest to researchers and industrialists, given their broad spectrum of action. Research in this area has grown significantly, and chemical and pharmacological studies of these substances have provided a better approach to the relationship between structure and activity.

Heterocycles are the largest and most diverse family of organic compounds [1]-[9]. Thus, heterocycles constitute the largest and most diverse family of organic compounds [1][9]. Heterocyclic amino acids play a predominant role in the synthesis of peptides and proteins [10]-[13], and so far they have aroused the interest of researchers, who study their structure-activity relationship thus allowing a better approach to understanding their mechanisms of action. The synthesis of new carboxylic amino acids and their esters has become a major interest for research teams around the world [14]-[21]. Their applications are in various fields: enzymology [22][25]; medicine and pharmacology [26]-[30]; industry [31] and asymmetric synthesis [32]-[34].

Finally, recently published works have revealed the interest of heterocyclic $\alpha$-aminoesters derivatives as antioxidant agents [35], [36], which encouraged us to test the antioxidant effect of five products, which we synthesized in our laboratory, using the DDPH and Ferric Reducing Antioxidant Power (FRAP) tests.

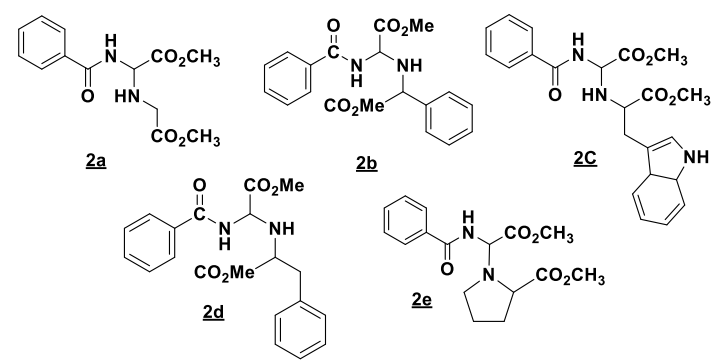

Fig. 1. Structures of the five synthesised molecules tested.

\section{RESULTS AND DISCUSSION}

\section{A. Chemistry}

The nucleophilic substitution reaction of methyl 2-azido2-benzamidoacetate $\underline{\mathbf{1}}$ with different derivatives of heterocyclic and non-heterocyclic aminoesters was promoted by the use of a base in dichloromethane or acetone as a solvent. The reaction is followed by CCM along the reaction time. The desired products were obtained with satisfactory yields ranging from 70 to $86 \%$ (Scheme 1 and Table I).

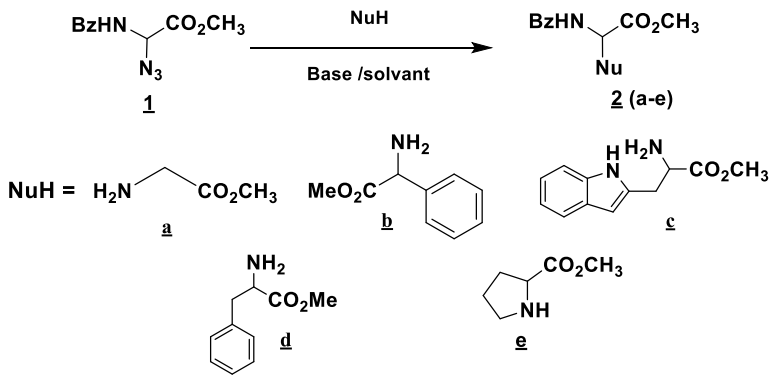

Scheme 1. Strategy for the synthesis of new carboxylic $\alpha, \alpha$-diaminoesters derivatives.
TABLE I: REACTION CONDITIONS FOR N-ALKYLATION

\begin{tabular}{|c|c|c|c|c|c|c|}
\hline Comp. & $\begin{array}{l}\text { Reaction } \\
\text { time }\end{array}$ & $\begin{array}{l}\text { Rdt, } \\
(\%)\end{array}$ & $\begin{array}{c}\text { Physical } \\
\text { aspect }\end{array}$ & $\begin{array}{l}\text { Melting } \\
\text { point } \\
\left({ }^{\circ} \mathrm{C}\right)\end{array}$ & $\begin{array}{c}\text { Base /Solvent/ } \\
\text { (No. of Nu-H eq.) }\end{array}$ & $\mathrm{Rf}$ \\
\hline$\underline{2 a}$ & $48 \mathrm{~h}$ & 80 & Qid & - & $\begin{array}{l}\text { DIEA/Acetone } \\
(1.2 \mathrm{eq} . \text { of } \mathrm{Nu}-\mathrm{H})\end{array}$ & $\begin{array}{c}0.62 \\
\text { (hexane/acetone, 1:1) }\end{array}$ \\
\hline$\underline{2 b}$ & $16 \mathrm{~h}$ & 86 & $\begin{array}{l}\text { Solid } \\
\text { white }\end{array}$ & $126-128$ & $\begin{array}{l}\text { NEt3/Dichloromethane } \\
\text { (1.1eq. of Nu-H) }\end{array}$ & $\begin{array}{c}0.35 \\
\text { (hexane/acetate, 8:2). }\end{array}$ \\
\hline$\underline{2 c}$ & $72 \mathrm{~h}$ & 86 & $\begin{array}{l}\text { Solid } \\
\text { white }\end{array}$ & $174-176$ & $\begin{array}{l}\text { DIE.A/Acetone } \\
\text { (1.2eq. of Nu-H) }\end{array}$ & $\begin{array}{c}0,71 \\
\left(\mathrm{CH}_{2} \mathrm{Cl}_{2} / \text { acetate, } 8: 2\right)\end{array}$ \\
\hline$\underline{2 \mathrm{~d}}$ & $24 \mathrm{~h}$ & 70 & $\begin{array}{l}\text { Solid } \\
\text { white }\end{array}$ & $90-92$ & $\begin{array}{l}\text { DIEA/Acetone } \\
\text { (1.2eq. of } \mathrm{Nu}-\mathrm{H})\end{array}$ & $\begin{array}{c}0,65 \\
\text { (hexane/acetate, 1:1) }\end{array}$ \\
\hline$\underline{\underline{2 e}}$ & $48 \mathrm{~h}$ & 75 & Qid & - & $\begin{array}{l}\text { DIEA/Acetone } \\
\text { (1.2eq. of Nu-H) }\end{array}$ & $\begin{array}{c}0.69 \\
\text { (hexane/acetone, 3:2) }\end{array}$ \\
\hline
\end{tabular}

The N-benzoylated methyl 2-azido glycinate derivative $\underline{\mathbf{1}}$ was prepared by the method of Steglich [37] and the procedure of Achamlale [38], [39] by the action of sodium azide with methyl $\alpha$-bromo glycinate derivative.

The structures of the prepared compounds were established on the basis of ${ }^{1} \mathrm{H}$ and ${ }^{13} \mathrm{C}$ 1D NMR, ${ }^{1} \mathrm{H}-{ }^{1} \mathrm{H}$ and ${ }^{1} \mathrm{H}_{-}{ }^{13} \mathrm{C} 2 \mathrm{D}$ homonuclear and heteronuclear NMR, Mass spectrometry, and Elemental analysis data. Two compounds from this series were isolated as single crystals and their chemical structures were determined by X-ray diffraction.

Thus, the compound (2R)-2-benzamido-2-\{[(1R)-2methoxy-2-oxo-1-phenylethyl]amino methyl acetate $\underline{\mathbf{2 b}}$ with the empirical formula $\mathrm{C}_{19} \mathrm{H}_{20} \mathrm{~N}_{2} \mathrm{O}_{5}$, crystallizes in the Orthorhombic system with the space group P212121 [40] (Fig. 2)

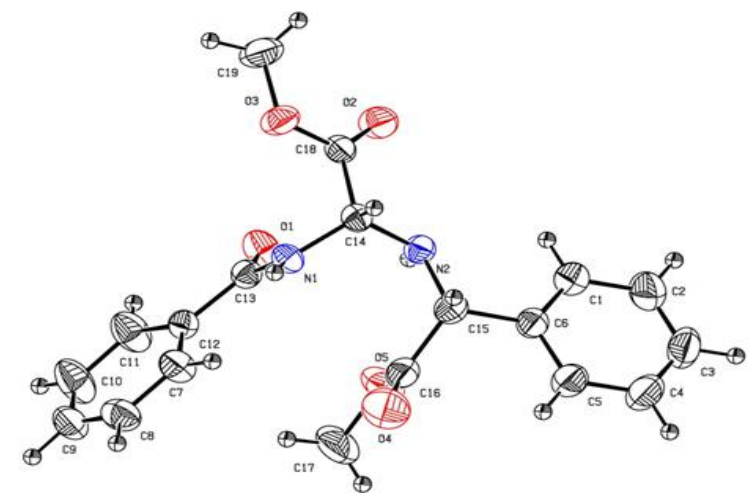

Fig.2. ORTEP view of compound $\underline{2 b}$ showing the atomic numbering scheme.

The methyl 2-((1-benzamido-2-methoxy-2oxoethyl)amino) -3-(3a,7a-dihydro-1H-indol-3yl)propanoate derivative $\underline{\mathbf{2 c}}$, with the empirical formula $\mathrm{C}_{22} \mathrm{H}_{23} \mathrm{~N}_{3} \mathrm{O}_{2}$, crystallizes in the Orthorhombic system with space group $\mathrm{P} 212121[41]$.

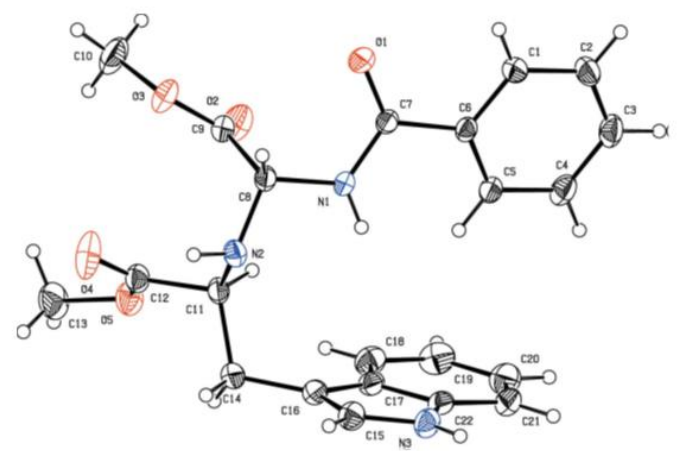

Fig.3. ORTEP view of compound $\underline{\mathbf{2 c}}$ showing the atomic numbering scheme. 


\section{B. Antioxidant Activity}

Antioxidant activity defines the ability of an organism to protect itself against free radicals. The best-known antioxidants are $\beta$-carotene (provitamin A), ascorbic acid (vitamin C), tocopherol (vitamin E), and phenolic compounds. Indeed, the antioxidant properties of most synthetic or naturally occurring antioxidants are attributed in part to the ability of these natural compounds to trap free radicals such as hydroxyl $(\mathrm{OH} \bullet)$ and superoxides $(\mathrm{O} \bullet)$ radicals. [42], [43].

\section{Main methods for assessing antioxidant activity}

There is a wide variety of physico-chemical methods to evaluate the antioxidant activity of natural extracts. Several methods are used to analyse the distinct steps of the oxidation process, such as the measurement of the weakening of the substrate, and/or the consumption of oxygen during oxidation; the formation of oxidation products, and the ability to trap free radicals in different phases.

\subsection{TEAC (Trolox Equivalent Antioxidant Capacity) method}

This method was first described by Miller and Rice-Evans [44], then improved in 1999 by these authors [45]. In fact, it consists of the reduction of the coloured radical-cation $(2,2$ 'azobis 3 ethylbenzothiazoline-6-sulphonic acid) better known under the name of ABTS•+. The development of its concentration at $734 \mathrm{~nm}$ is monitored during its reaction with the antioxidants. Antioxidant capacity is measured as the concentration ( $\mathrm{mM}$ ) of Trolox (a soluble vitamin E analogue) producing the same effect as the test sample on ABTS reduction [46]. The literature provides TEAC of some antioxidants (Vitamin $\mathrm{C}=0.99 \mathrm{mM}, \beta$-carotene $=1.9 \mathrm{mM}$ ).

\subsection{DPPH (1, 1-Diphenyl-2-picryhydrozyl) test}

According to Rivero-Pérez and Brand-Williams [47], antioxidant capacity can also be measured using more stable free radicals. The 1,1-diphenyl-2-picrylhydrazyl radical (DPPH) is a very stable free radical in the crystalline state and in solution, with a purple coloration. By this method, antioxidant activity is considered to be the ability of antioxidants to act as a trap for free radicals. They act by transferring a hydrogen atom, which leads to the disappearance of the DPPH radical during the reaction, and a change of colouring in the initial solution. The progression of the reaction is followed by spectrophotometry at $516 \mathrm{~nm}$. The more easily a compound gives away its hydrogen atom, the more it is considered to be effective as an antioxidant. The percentage of the remaining DPPH is proportional to the concentration of the antioxidant. The concentration of the phenolic compound required to achieve a 50\% loss of DPPH at equilibrium is known as IC50. The DPPH method has been used by many authors, due to its speed and reproducibility.

\subsection{Ferric Reducing Antioxidant Power (FRAP)}

The FRAP method developed by Benzie and Strain [48], corresponds to the reduction of a ferric tripyridyltriazine complex [(Fe(III)-TPTZ)2] to a ferrous tripyridyltriazine complex [(Fe(II)-TPTZ)2] by an antioxidant (AH), at a $\mathrm{pH}$ of 3.6 , in order to maintain the solubility of iron. To ensure the linearity of the method and to calculate the results, a standard range is first performed with an aqueous solution of iron sulphate heptahydrate $\left(\mathrm{FeSO}_{4}-7 \mathrm{H}_{2} \mathrm{O}\right)$ between 100 and
$1000 \mu \mathrm{M}$. From the absorbance values read at $593 \mathrm{~nm}$ and measured at $\mathrm{t}=0 \mathrm{~min}$ and at $\mathrm{t}=4 \mathrm{~min}$ after mixing.

\subsection{ORAC (Oxygen Radical Absorbance Capacity) method}

It consists of a measurement of the protection exerted by a given substance or molecule against the oxidation of fluorescein by the radical derivatives of the thermolytic degradation of the AAPH radical. Unlike the DPPH test, which measures a reduction capacity, it is therefore strictly speaking a measure of antiradical power. The results are expressed in relation to the protection provided by a reference antioxidant, Trolox, and are reported per gram of product tested. When fluorescein is subjected to the oxidative action of a free radical, AAPH, we observe that its fluorescence response decreases over time (about 10 minutes). In the presence of an anti-free radical activity (compound, natural product, etc.) fluorescein is protected from stress and the duration of its fluorescence is increased. It is this increase that allows the antiradical power to be quantified via a calibration by Trolox.

\subsection{Bleaching method for $\beta$-carotene}

The bleaching test of detergent-carotene is used to evaluate the antioxidant activity of plant extracts, which consists in following the decoloration kinetics of detergent-carotene by the oxidation products of linoleic acid in the presence of an antioxidant. $\beta$-carotene is a lipophilic antioxidant that protects fatty acids from oxidation; the addition of a second antioxidant will preserve it [49]. The greater the effectiveness of an antioxidant, the slower the colour fading of $\beta$-carotene and vice versa [50], [51].

\subsection{Hydroxyl radical scavenging (HRSA)}

Following the Haber Weiss reaction [52], $\bullet \mathrm{OH}$ is the highly reactive free radical formed in biological systems from superoxide anion and hydrogen peroxide in the presence of metal ions such as iron and copper. This radical has a free electron with a higher reduction potential $(2310 \mathrm{mV})$ allowing it to act with lipids, proteins, polypeptides and DNA particularly thiamine and guanine [53]. In vitro, the ability to trap the hydroxyl radical by plant extracts is based on the Fenton reaction by measuring the generation of the $\cdot \mathrm{OH}$ radical and its effect on the oxidation and degradation of biological molecules, such as DNA deoxyribose's. In this technique, the system involves the self-oxidation of the $\mathrm{Fe} 2+-$ EDTA complex in an aqueous medium to form $\mathrm{O}^{\cdot 2-}$, which is rapidly dismuted into $\mathrm{H}_{2} \mathrm{O}_{2}$ at $\mathrm{pH}$ 7.4. The latter than interacts with $\mathrm{Fe}^{2+}$ to form the $\cdot \mathrm{OH}$ radicals in the presence of ascorbic acid as a catalyst (Fenton reaction).

$$
\mathrm{H}_{2} \mathrm{O}_{2}+\mathrm{Fe}^{2+}-\mathrm{EDTA} \longrightarrow \cdot \mathrm{OH}+\mathrm{OH}^{-}+\mathrm{Fe}^{3+}-\mathrm{EDTA}
$$

\section{Scavenging power of the DPPH-radical}

The antioxidant activity of the synthesized products compared with ascorbic acid, used as a positive control, was determined by the DPPH method. This activity was evaluated using a visible UV spectrophotometer by monitoring the reduction of this radical, which is accompanied by its transition from the violet colour (DPPH•) to the yellow colour (DPPH-H), which can be measured at $515 \mathrm{~nm}$ [54]. 
TABLE II: IC50 VALUES OF THE CRUDE EXTRACTS AND THE CONTROL, DETERMINED BY THE DPPH TEST

\begin{tabular}{|c|c|}
\hline Retrieved from & IC50 $(\mathrm{mg} / \mathrm{ml})$ \\
\hline $\begin{array}{l}\text { Methyl 2-benzamido-2-((2-methoxy-2- } \\
\text { oxoethyl)amino)propanoate } \underline{\mathbf{2 a}}\end{array}$ & 0,49 \\
\hline $\begin{array}{l}\text { Methyl (2R)-2-benzamido-2-\{[(1R)-2-methoxy-2- } \\
\text { oxo- 1-phenylethyl]amino }\} \text { acetate } \underline{\mathbf{2 b}}\end{array}$ & 0,19 \\
\hline $\begin{array}{l}\text { methyl 2-((1-benzamido-2-methoxy-2- } \\
\text { oxoethyl)amino)-3-(3a,7a-dihydro-1H-indol-3- } \\
\text { yl)propanoate } \underline{\mathbf{2 c}}\end{array}$ & 0,74 \\
\hline $\begin{array}{l}\text { Methyl 2-((1-benzamido-2-methoxy-2- } \\
\text { oxoethyl)amino)-3-phenylpropanoate } \underline{\mathbf{2 d}}\end{array}$ & 0,92 \\
\hline $\begin{array}{l}\text { Methyl 1-(1-benzamido-2-methoxy-2-oxoethyl) } \\
\text { pyrrolidine-2-carboxylate } \underline{\mathbf{2}}\end{array}$ & 1,18 \\
\hline Ascorbic acid & 0,083 \\
\hline
\end{tabular}

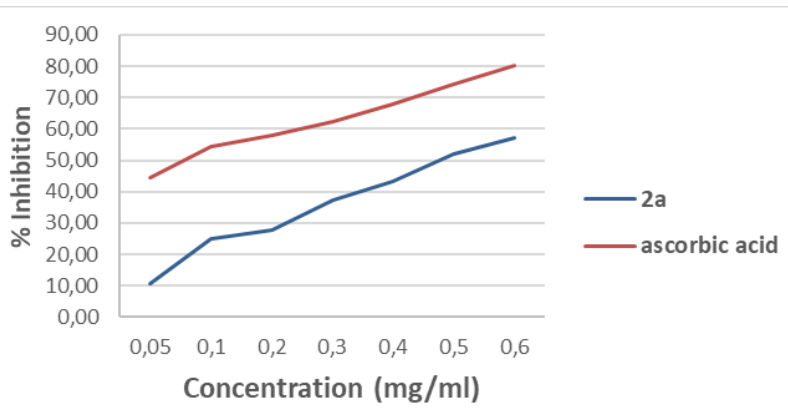

Fig.4. Antioxidant activity of extract $\underline{\mathbf{2 a}}$ compared to ascorbic acid.

Among the five extracts tested, extract $\underline{\mathbf{2 b}}$ is an effective antioxidant compared to the other extracts. Nevertheless, the power of the reference antioxidant remains higher than that of the studied extracts. In the light of the results obtained, we can conclude that the various extracts tested have a significant antioxidant power compared to the positive control considered.

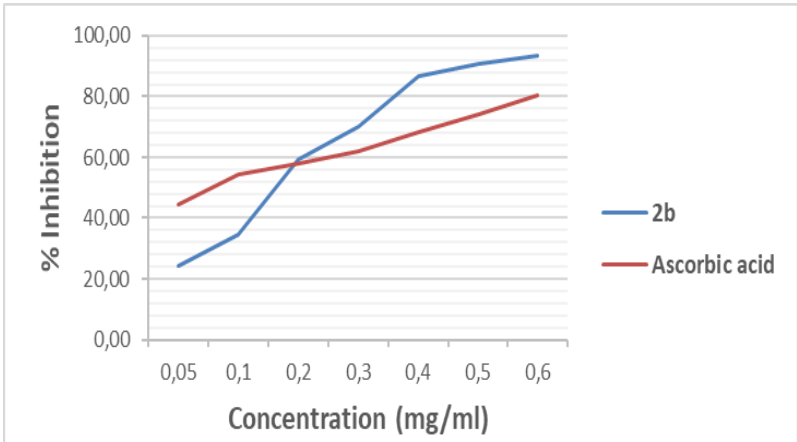

Fig.5. Antioxidant activity of extract $\underline{\mathbf{2} b}$ compared to ascorbic acid.

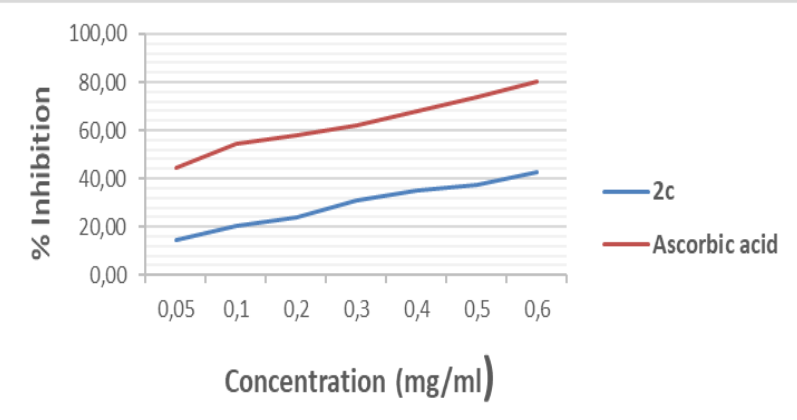

Fig.6. Antioxidant activity of extract $\underline{\mathbf{2 c}}$ compared to ascorbic acid.

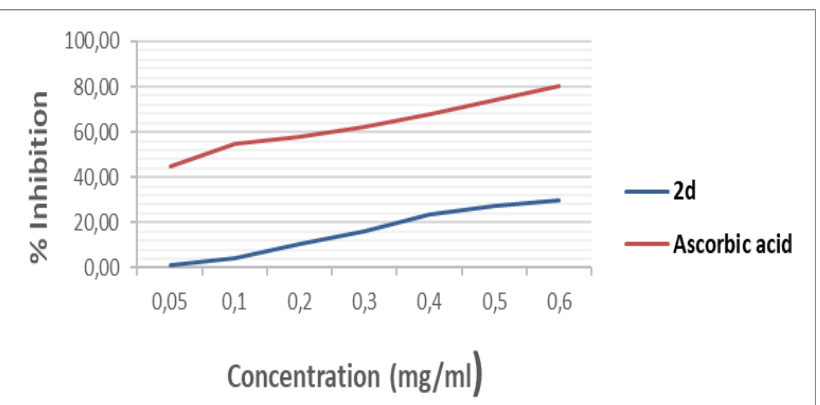

Fig.7. Antioxidant activity of $\underline{\mathbf{2 d}}$ extract compared to ascorbic acid.

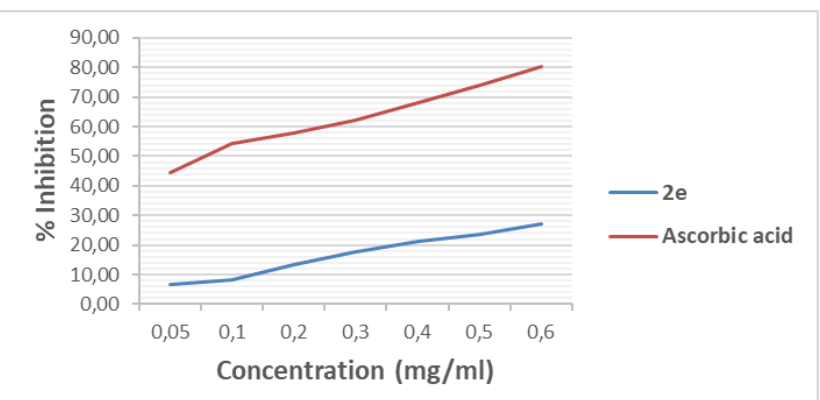

Fig.8. Antioxidant activity of extract $\underline{\mathbf{2 e}}$ compared to ascorbic acid.

\section{Reducing power (FRAP)}

For the FRAP method, the revelation of reducing power is based on the shift from the yellow colour of potassium ferrocyanide to a greenish blue colour whose intensity depends on the reducing power of each sample. The latter depends mainly on the quantity of reducer present in the tested medium. This translates into an increase in absorbance measured at $700 \mathrm{~nm}$ [55]. The results show that the reductive power of synthetic extracts is based on their concentrations used. It is noted that the reductive power of the tested extracts remains lower than that of the reference antioxidant (ascorbic acid).

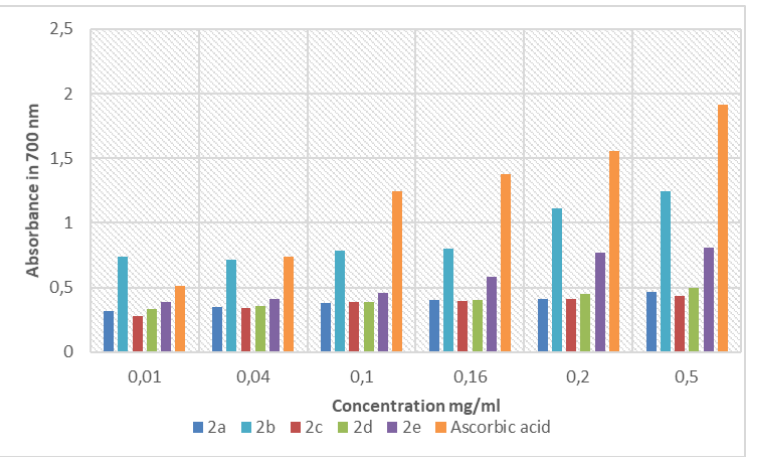

Fig. 9. Reducing power of synthetic extracts compared to ascorbic acid.

The lower the IC50 value, the greater the antioxidant activity of a compound. The results obtained are grouped in the table given below:

TABLE III. IC50 VALUES (MG/ML) OF CRUDE AND CONTROL EXTRACTS

\begin{tabular}{cc}
\multicolumn{2}{c}{ DETERMINED } \\
\hline \hline Retrieved from & IC50 $(\mathrm{mg} / \mathrm{ml})$ \\
\hline$\underline{2 \mathrm{a}}$ & 176,41 \\
$\frac{2 \mathrm{~b}}{2 \mathrm{c}}$ & 43,66 \\
$\underline{\underline{2 \mathrm{~d}}}$ & 194,55 \\
$\underline{2 \mathrm{e}}$ & 155,88 \\
Ascorbic acid & 54,6 \\
\end{tabular}


The results show that the compounds tested are electron donors and are able to reduce $\mathrm{Fe}^{3+}$ ions linearly as a function of concentration. These results are compared with the standard antioxidant (ascorbic acid). At concentrations ranging from 0.01 to $0.5 \mathrm{mg} / \mathrm{ml}$, extract $\underline{\mathbf{2 b}}$ has the most significant reducing power, followed by extracts $\underline{\mathbf{2 e}}, \underline{\mathbf{2 d}}, \underline{\mathbf{2 a}}$ and $\underline{\mathbf{2 c}}$, respectively.

\section{MATERIALS AND METHODS}

All solvents were purified following the standard techniques and commercial reagents were purchased from Sigma-Aldrich (St. Louis, MO, USA). Melting point was determined with an Electrothermal melting point apparatus and was uncorrected. NMR spectra $\left({ }^{1} \mathrm{H}\right.$ and $\left.{ }^{13} \mathrm{C}\right)$ were recorded on a Bruker AM 300 spectrometer (operating at $300.13 \mathrm{MHz}$ for $1 \mathrm{H}$, at $75.47 \mathrm{MHz}$ for 13C) (Bruker Analytische Messtechnik GmbH, Rheinstetten, Germany). NMR data are listed in $\mathrm{ppm}$ and are reported relative to tetramethylsilane $\left({ }^{1} \mathrm{H},{ }^{13} \mathrm{C}\right)$; residual solvent peaks being used as internal standard. All reactions were followed by TLC. TLC analyses were carried out on $0.25 \mathrm{~mm}$ thick precoated silica gel plates (Merck Fertigplatten Kieselgel 60F254) and spots were visualized under UV light or by exposure to vaporized iodine. Mass spectra were recorded on a PolarisQ Ion Trap GC/MSn Mass Spectrometer (CNRST-Rabat). The Orteps of compounds $\underline{\mathbf{2 b}}$ and $\underline{\mathbf{2 c}}$ were obtained on a Bruker APEXII CCD detector diffractometer (CNRST-Rabat).

\section{A. Chemistry}

\section{N-alkylation reaction}

To $11 \mathrm{mmoles}$ of nucleophile (Nu-H), $50 \mathrm{ml}$ of anhydrous solvent (dichloromethane or acetone) is added, the mixture is cooled to $0^{\circ} \mathrm{C}$, then $22 \mathrm{mmoles}$ of base (triethylamine, DIEA) is added, followed by 10 mmoles of $\mathrm{N}$-protected methyl $\alpha$ azidoglycinate $\underline{\mathbf{1}}$. The mixture is stirred for one hour at $0^{\circ} \mathrm{C}$ and then at room temperature. The reaction is monitored by TLC along the reaction time. The solvent is evaporated under reduced pressure. The residue obtained is quenched with a $15 \%$ citric acid solution and extracted with methylene chloride. The organic phase is washed with a saturated solution of sodium hydrogen carbonate $\left(\mathrm{NaHCO}_{3}\right)$, dried with $\mathrm{Na}_{2} \mathrm{SO}_{4}$ and the solvent is evaporated. The residue obtained is either chromatographed on a silica gel column (eluent: ethyl acetate/hexane) or recrystallized in ether.

Methyl

2-benzamido-2-((2-methoxy-2oxoethyl)amino)acetate 2a: Rdt.: $80 \%$ (oil) ; Rf $=0,62$ (hexane/acetone, 1:1). ${ }^{\mathbf{1}} \mathbf{H}-\mathbf{N M R}(\mathrm{CDCl} 3, \delta \mathrm{ppm}): 3.15\left(\mathrm{e},{ }^{1} \mathrm{H}\right.$, NH- $\left.\mathrm{CH}_{2-}\right) ; 3.47-3.62\left(\mathrm{dd}, 2 \mathrm{H}, \mathrm{NH}-\mathrm{CH}_{2}-, J_{l}=5.6 \mathrm{~Hz}, J_{2}=6.4\right.$

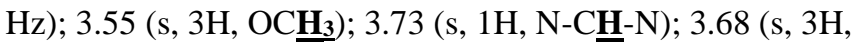
$\left.\mathrm{OC}_{\mathbf{H}}\right) ; 5.44(\mathrm{~d}, 1 \mathrm{H}, \mathrm{N} \underline{\mathrm{H}}-\mathrm{Bz}, J=7.84 \mathrm{~Hz}) ; 7.3-7.8(\mathrm{~m}$, 5Harom). ${ }^{13} \mathbf{C}-\mathbf{N M R}\left(\mathrm{CDCl}_{3}, \delta \mathrm{ppm}\right): 46.85\left(1 \mathrm{C}, \underline{\mathrm{CH}}_{2}-\mathrm{C}\right)$; 51.87 et $52.74\left(2 \mathrm{C}, \mathrm{OCH}_{3}\right) ; 64.81$ (1C, N- $\left.\underline{\mathrm{CH}}-\mathrm{N}\right) ; 127.21$ 133.29 (6C, Carom); $167.49,170.22$ et 172.79 (3C, $\underline{\text { CO). }}$

Methyl (2R)-2-benzamido-2-\{[(1R)-2-methoxy-2-oxo-1phenyl ethyl]amino\}acetate $\underline{\mathbf{2 b}}$ [56]

Methyl 2-((1-benzamido-2-methoxy-2-oxoethyl)amino)3-(3a,7a-dihydro-1H-indol-3-yl)propanoate 2c [57].

Methyl 2-((1-benzamido-2-methoxy-2-oxoethyl)amino)-3phenyl propanoate $\underline{2 d}$ : Rdt. : $70 \%$ (solid white) ; F $=90-92^{\circ}$.
$\mathrm{C}^{\mathbf{1}} \mathbf{H}-\mathbf{N M R}\left(\mathrm{CDCl}_{3}, \delta \mathrm{ppm}\right): 2.73\left(\mathrm{e}, 1 \mathrm{H}, \mathrm{N} \underline{\mathrm{H}}-\mathrm{CH}-\mathrm{CH}_{2}-\mathrm{Ph}\right)$;

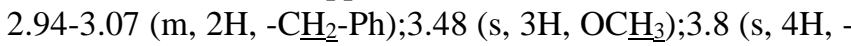
C$\left.-\mathrm{CH}_{2}-\mathrm{Ph}+\mathrm{OC}_{3}\right) ; 5.51-5.53(\mathrm{~d}, 1 \mathrm{H}, \mathrm{N}-\underline{\mathrm{C}} \underline{\mathrm{H}}-\mathrm{N}, J=8.15$ $\mathrm{Hz})$; 6.72-6.74 (d, $1 \mathrm{H}, \mathrm{NHBz}, J=8.14 \mathrm{~Hz}) ; 7.17-7.76(\mathrm{~m}$, $\left.10 \mathrm{H}, 10 \mathrm{H}_{\text {arom }}\right) .{ }^{13} \mathbf{C}-\mathbf{N M R}\left(\mathrm{CDCl}_{3}, \delta \mathrm{ppm}\right): 39.77\left(1 \mathrm{C},-\mathrm{CH}_{2}-\right.$ $\mathrm{Ph}) ; 51.90$ et $52.77\left(2 \mathrm{C}, \mathrm{OCH}_{3}\right) ; 59.61$ (1C, $\left.-\underline{\mathrm{CH}}-\mathrm{CH}_{2}-\mathrm{Ph}\right)$; 64.47 (1C, N-ㄷH-N); 126.86-136.61 (10C, $\left.\mathrm{C}_{\text {arom }}\right) ; 166.86$, 170.02 et $175.54\left(3 \mathrm{C}\right.$, CO).MS $m / z(\%)=\mathbf{3 7 0 , 1 5} . \mathrm{C}_{20} \mathrm{H}_{22} \mathrm{~N}_{2} \mathrm{O}_{5}$ (\%), Calculated values: $\mathrm{C}, 64.85 ; \mathrm{H}, 5.99 ; \mathrm{N}, 7.56$; Values found (\%): C64.82, H 6.02, N 7.58.

Methyl 1-(1-benzamido-2-methoxy-2-oxoethyl) pyrrolidine-2-carboxylate 2e: Rdt.: $75 \%$ (oil); ${ }^{1} \mathbf{H}-\mathbf{N M R}$ $\left(\mathrm{CDCl}_{3}, \delta \mathrm{ppm}\right): 1.26-1.38$ (m, 2H, $\left.-\mathrm{CH}_{2}-\mathrm{CH}_{2}-\mathrm{CH}-\right)$; 1.79 $1.88\left(\mathrm{~m}, 2 \mathrm{H},-\mathrm{CH}_{2}-\mathrm{C}_{2} \underline{\mathrm{CH}}_{2}-\right.$ ); 2.84-3.05 (m, 2H, NH-C $\underline{\mathrm{H}}_{2}-$ $\left.\mathrm{CH}_{2}-\right) ; 3.80$ (s, $\left.3 \mathrm{H}, \mathrm{OC}_{\underline{3}}\right) ; 3.86$ (s, $\left.3 \mathrm{H}, \mathrm{OC}_{3}\right)$ ); 4.21-4.24 (dd, $\left.1 \mathrm{H},-\mathrm{CH}_{2}-\mathrm{CH}-, J_{l}=3.60 \mathrm{~Hz}, J_{2}=5.85 \mathrm{~Hz}\right) ; 5.69-5.71(\mathrm{~d}, 1 \mathrm{H}$, $\mathrm{N}-\mathrm{C} \underline{\mathrm{H}}-\mathrm{N}, J=6.0 \mathrm{~Hz}) ; 5.84(\mathrm{~d}, 1 \mathrm{H}, \mathrm{N} \underline{\mathrm{H}}-\mathrm{Bz}, J=6.0 \mathrm{~Hz}) ; 7.44-$ 7.87 (m, 5Harom). ${ }^{13} \mathbf{C}-\mathbf{N M R}\left(\mathrm{CDCl}_{3}, \delta \mathrm{ppm}\right): 23.04(1 \mathrm{C}$, $\mathrm{CH}_{2}-\mathrm{CH}_{2}-\mathrm{CH}_{2-}$ ); 29.70 (1C, - $\left.\mathrm{CH}_{2}-\underline{\mathrm{CH}}_{2}-\mathrm{CH}-\right)$; 52.13 (1C, -

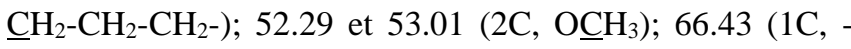
$\left.\mathrm{CH}_{2}-\mathrm{CH}_{2}-\underline{\mathrm{CH}}-\right) ; 68.16$ (1C, N-ㅌH-N); 127.22-133.23 (6드, Carom); $168.01,170.14$ et 174.49 (3C, $\underline{\mathrm{CO}})$.

\section{B. Antioxidant Power}

\section{Measurement of the DPPH-radical scavenging capacity}

The protocol followed in this analysis is that described by Huang et al. [58]. First, we prepare the parent solution of DPPH at a concentration of $60 \mu$ mole, so we put $2.4 \mathrm{mg}$ of DPPH in $100 \mathrm{ml}$ of methanol. After stabilization of this solution, take $3.8 \mathrm{ml}$ and add to $200 \mu \mathrm{l}$ of the extract already prepared, and mix with a vortex. After $30 \mathrm{~min}$ of incubation in darkness and at room temperature, the optical density (DO) reading is performed at $515 \mathrm{~nm}$. A vitamin $\mathrm{C}$ concentration range (L-ascorbic acid) was prepared for comparison in the analysis of the results. All tests were performed in triplicate.

\section{Reducing power (FRAP)}

The reductive power of the samples was determined using the Benzie principle [59]. The protocol adopted was as follows: $250 \mu \mathrm{l}$ of pre-prepared sample extract is added to a mixture of $250 \mu \mathrm{l}$ of a phosphate buffer solution $(200 \mathrm{mM}$, $\mathrm{pH} 6,6)$, and $250 \mu \mathrm{l}$ of $1 \%$ potassium ferricyanure $(\mathrm{p} / \mathrm{v})$. The set was incubated in a $50{ }^{\circ} \mathrm{C}$ water bath for 20 minutes, then $250 \mu 10 \%$ trichloroacetic acid (w/v) was added to the mixture. Then we centrifuge at $10000 \mathrm{ppm}$ for $10 \mathrm{~min} .1 \mathrm{ml}$ of the supernatant is recovered, $1 \mathrm{ml}$ of distilled water is added and $0,1 \mathrm{ml}$ of ferric chloride solution $(0,1 \%, \mathrm{w} / \mathrm{v})$. The absorbance of the reaction medium is read at $700 \mathrm{~nm}$ against a similar white, replacing the extract with distilled water, which allows to calibrate the device. Positive control is represented by a solution of a standard antioxidant: Ascorbic acid, the absorbance of which is measured under the same conditions as the samples.

\section{CONCLUSION}

Based on the structural model of methyl $\alpha$-azidoglycinate, we synthesized a new heterocyclic and non-heterocyclic systems based on the $\mathrm{N}$-alkylation reaction of methyl 2azido-2-benzamidoacetate with a series of carboxylic aminoesters. The synthesised compounds were tested in vitro 
for their antioxidant activity using the radical scavenging power (DPPH), and reducing power (FRAP) tests. The results reveal that the tested compounds are electron donors and are able to reduce $\mathrm{Fe} 3+$ ions in a linear concentration-dependent manner. These results are compared with the standard antioxidant (ascorbic acid). At concentrations ranging from 0.01 to $0.5 \mathrm{mg} / \mathrm{ml}$, Methyl (2R)-2-benzamido-2- $\{[(1 \mathrm{R})-2-$ methoxy-2-oxo-1-phenylethyl]amino $\}$ acetate $\underline{\mathbf{2 b}}$ has the most significant reducing power followed by $\underline{\mathbf{2 e}}, \underline{\mathbf{2 d}}, \underline{\mathbf{2 a}}$ and 2c, respectively.

It should be noted that the DPPH test performed on aminoesters synthesized by Galeshshahi et al. [60], showed that all tested extracts exhibited significant antioxidant activity, with IC50 values ranging from 3,9-33,6 \% compared with the reference antioxidant butylated hydroxytoluene or 2,6-di-tert-butyl-4-methylphenol (BHT), which had a value of $1,1 \%$.

While our synthesized products, carboxylic $\alpha, \alpha-$ diaminodiesters had IC50 values ranging from $0.19-1.18 \%$ compared with the reference antioxidant which had a value of $0.018 \%$. As a result, both results show that the antioxidant activity of this family of molecules, despite its importance, is still less important than that of the reference antioxidant.

\section{ACKNOWLEDGMENT}

This work was supported by Sidi Mohammed Ben Abdellah University (USMBA) and National Center for Scientific and Technical Research (CNRST).

\section{REFERENCES}

[1] Dhanapal, V., Ramalingam, J., Raman, A.N. Synthesis, Characterization and Antimicrobial Activity of 1,2 dihydroquinoxaline-3-yl-3-Substitutedphenyl-1H-pyrazole-4Carbaldehyde. J. Heterocyclic Chem., 2017, 54(2). https://doi.org/10.1002/jhet.2663.

[2] Faidallah, H. M., Rostom, S. A. F. Synthesis, Anti-Inflammatory Activity, and COX-1/2 Inhibition Profile of Some Novel Non-Acidic Polysubstituted Pyrazoles and Pyrano[2,3-c]pyrazoles. Arch. Pharm. Chem. Life Sci., 2017, 350(5), e1700025. https://doi.org/10.1002/ardp.201700025.

[3] Ansari, A., Ali, A., Asif, M., Shamsuzzaman. Review: biologically active pyrazole derivatives. New J. Chem., 2017, 41, 16-41. https://doi.org/10.1039/C6NJ03181A.

[4] Rao, N. S., Shaik, A. B., Routhu, S. R., Ali Hussaini, S. M., Sunkari, S., Rao, A. V. S., Reddy, A. M., Alarifi, A., Kamal, A. New Quinoline Linked Chalcone and Pyrazoline Conjugates: Molecular Properties Prediction, Antimicrobial and Antitubercular Activities. Chemistry Select., 2017, 2, 2989-2996. https://doi.org/10.1002/slct.201602022.

[5] Sadashiva, R., Naral, D., Kudva, J., Kumar, S. M., Shafeeulla R, M., Kumsi, M. Synthesis, structure characterization, in vitro and in silico biological evaluation of a new series of thiazole nucleus integrated with pyrazoline scaffolds. J. Mol. Struct., 2017, 1145, 18 https://doi.org/10.1016/j.molstruc.2017.05.066.

[6] Lin, B., Zhang, W. H., Wang, D. D., Gong, Y.,Wei, Q. D., Liu, X. L., Feng, T. T., Zhou, Y., Yuan, W. C. 3-Methyl-4-nitro-5-isatylidenylisoxazoles as 1,3-dipolarophiles for synthesis of polycyclic 3,3' pyrrolidinyl-dispirooxindoles and their biological evaluation for anticancer activities. Tetrahedron., 2017, 73, 5176 https://doi.org/10.1016/j.tet.2017.07.011.

[7] Madhavilatha, B., Fatima, N., Sabitha, G., Subba Reddy, B. V., Yadav, J. S., Bhattacharjee, D., Jain, N. Synthesis of 1,2,3-triazole and isoxazole-linked pyrazole hybrids and their cytotoxic activity. Med. Chem. Res., 2017, 26(8), 1753-1763.https://doi.org/10.1007/s00044017-1884-z.

[8] Bhardwaj, A. A Review on Azole Derivatives as Potent Anticancer Agents. International Journal of ChemTech Research., 2018,11(11): 154-175. http://dx.doi.org/10.20902/IJCTR.2018.111116.
[9] Zghab, I., Trimeche, B., Ben Mansour, M., Hassine, M., Touboul, D., Ben Jannet, H. Regiospecific synthesis, antibacterial and anticoagulant activities of novel isoxazoline chromene derivatives. Arabian J. Chem., 2017, 10, S2651-S2658, https://doi.org/10.1016/j.arabjc.2013.10.008.

[10] Chen, M., Heimer, P., Imhof, D. Synthetic strategies for polypeptides and proteins by chemical ligation, Amino Acids.,2015, 47,7:1283-99. https://doi.org/10.1007/s00726-015-1982-5

[11] Sadiq A., Sewald, N.t. 6-Alkynyl- and 6-Aryl-Substituted (R)Pipecolic Acid Derivatives. Amino Acids., 2013, 252813, https://doi.org/10.1021/o14010728.

[12] Kotha, S., Shah, V. R., Halder, S., Vinodkumar, R. and Lahiri, K. Synthesis of bis-armed amino acid derivatives via the alkylation of ethyl isocyanoacetate and the Suzuki-Miyaura cross-coupling reaction. Amino Acids., 2007, 32: 387-394. https://doi.org/10.1007/s00726006-0402-2.

[13] Mallakpour, Sh., Mirkarimi, F. Synthesis and characterization of novel, optically active polyamides derived from S-valine natural amino acid and bulky anthracenic side chain. Amino Acids.,2010,39:1255-1263. https://doi.org/10.1007/s00726-010-0560-0.

[14] Mrkus, L., Batinić, N. J., Bjelišs, Jakas, A. Synthesis and biological evaluation of quercetin and resveratrol peptidyl derivatives as potential anticancer and antioxidant agents, Amino Acids.,2018, 51,2, 319-329. https://doi.org/10.1007/s00726-018-2668-6.

[15] Naydenova, E., Troev, K., Topashka-Ancheva, M., Hagele, G., Ivanov, I. and Kril, A. Synthesis, cytotoxicity and clastogenicity of novel $\alpha-$ aminophosphonic acids, Amino Acids., 2007, 33: 695-702. https://doi.org/10.1007/s00726-006-0459-y.

[16] Rosa Cristina, M., Ferreira, Maria Manuela, M., Susana, R., Costa, P. G. Heterocyclic amino acids as fluorescent reporters for transition metals: synthesis and evaluation of novel furyl-benzoxazol-5-yl-1alanines, New Journal of Chemistry.,2018,42, 3483-3492. DOI 10.1039/x0xx0000x.

[17] Golshadi Ghalehshahi, H., Balalaie, S., Aliahmadi, A., Moghimi, R. 4Aminocoumarin derivatives: synthesis and applications, Amino Acids.,2018, 50, 1461-1470. https://doi.org/10.1007/s00726-018 2624-5.

[18] Kotha, S., Shah, V. R., Halder, S., Vinodkumar, R. and Lahiri K. Synthesis of bis-armed amino acid derivatives via the alkylation of ethyl isocyanoacetate and the Suzuki-Miyaura cross-coupling reaction, Amino Acids.,2007,32: 387-394 https://doi.org/10.1007/s00726-0060402-2.

[19] Magafa, V., Borovic kova, L., Slaninova, J., Cordopatis, P. Novel analogues of arginine vasopressin containing $\alpha$-2-indanylglycine enantiomers in position 2, Amino Acids.,201038:1549-1559. https://doi.org/10.1002/psc.1189.

[20] Giovanni Roviello, N. Roberta I., Valentina R., Rosanna P., Hayarpi S., \& Caterina V. Synthesis and biological evaluation of a novel Amadori compound, Amino Acids.,2016 40,11, 9007-9011. https://doi.org/10.1007/s00726-016-2363-4

[21] Wang, B., Miao, Z. W., Wang, J., Chen2, R. Y., Zhang, X. D. Synthesis and biological evaluation of novel naphthoquinone fused cyclic aminoalkylphosphonates and aminoalkylphosphonic monoester, Amino Acids., 2008,35: 463-468. https://doi.org/10.1007/s00726-0070570-8.

[22] Mikolajczyk, M. J. Acyclic and cyclic aminophosphonic acids: asymmetric syntheses mediated by chiral sulfinyl auxiliary, Organomet. Chem.,2005, 690, 2488-2496. https://doi.org/10.1016/j.jorganchem.2004.10.045

[23] Meyer, F., Laaziri, A., Papini, A. M., Uziel, J., Juge, S., A novel phosphorus-carbon bond formation by ring opening with diethyl phosphite of oxazolines derived from serine, Tetrahedron.,2004, 60, 3593-3597. https://doi.org/10.1016/j.tet.2004.03.001.

[24] Rodrigues, R.S, da Silva, J.F., Boldrini-França, J., Fonseca, F.P.P., Otaviano, A.R., Henrique-Silva, F., Magro, A.J., Braz, A.S.K, dos Santos, J.I., Homsi-Brandeburgo, M.I. Structural and functional properties of Bp-LAAO, a new l-amino acid oxidase isolated from Bothrops pauloensis snake venomBiochimie.,2009, 91, 4, 490-501. https://doi.org/10.1016/j.biochi.2008.12.004.

[25] Samel, M., Tõnismägi, K., Rönnholm, G., Vija, H., Siigur, J., Kalkkinen, N., Siigur. 1-Amino acid oxidase from Naja oxiana venom, Comp. Biochem. Physiol.,2008, B 149, 572-580. https://doi.org/10.1016/j.cbpb.2007.11.008.

[26] De Lombaert, S., Blanchard, L., Tan, T., Sakane, Y., Berry, C., and. Ghai, R. D. Non-peptidic inhibitors of neutral endopeptidase Discovery and optimization of potency, Bioorg.Med. Chem. Lett., 1995, 5, 145. https://doi.org/10.1016/0960-894X(94)00474-T.

[27] Chou, L.C., Huang, L.J., Yang, J.S., Lee, F.Y., Teng, C.M., Kuo, S.C. Synthesis of furopyrazole analogs of 1-benzyl-3-(5-hydroxymethyl-2furyl)indazole (YC-1) as novel anti-leukemia agents, Bioorg. Med. 
Chem.,2007, 132, 15, 1732-1740. PMID: 17189698 https://doi.org/10.1016/j.bmc.2006.12.001.

[28] Li, J., Zhao, Y.F., Zhao, X.L., Yuan, X.Y., Gong, P. Synthesis and Anticancer Activities of Novel 1,4-Disubstituted Phthalazines, Molecules.,2006, 11, 574-582. PMID: 17971729. https://doi.org/10.3390/11070574.

[29] Elhenawy, A.A. Design, Synthesis of New Amino Acid Derivatives and Evaluate DNA Binding Activity, Anticancer and Antimicrobial Activity, Int. J. of Bioorg. Chem.,2017, 2, 36-50. https://doi.org /10.11648/j.ijbc.20170202.11.

[30] Yan, R.Z., Liu, X.Y., Xu, W.F., Pannecouque, C., Witvrouw, M., De Clercq, E. Synthesis and anti-HIV evaluation of the novel 2-(mchlorobenzyl)-4-substituted-7-methyl-1, 1, 3-trioxo-pyrazolo[4, 5-e] [1, 2, 4]thiadiazines, Arch. Pharm. Res. 2006, 29, 957-962. https://doi.org/10.1007/BF02969278.

[31] Manjari, S., Pandey, A., Chakrabarti, L. K., Pandey, S.K. Bhattacharya, Plasma isatin is increased in maternal anxiety and obstetrical stress, Stressand Health.,2002, 18, 133. https://doi.org/10.1002/smi.932.

[32] Amabili, P., Amici, A., Civitavecchia, A., Maggiore, B., Orena, M. S., Rinaldi, Tolomelli, A. Highly stable atropisomers by electrophilic amination of a chiral $\gamma$-lactam within the synthesis of an elusive conformationally restricted analogue of $\alpha$-methylhomoserine, Amino Acids., 2015,48,2:461-78. https://doi.org/10.1007/s00726-015-2100-4

[33] Reider, P.J., Eichen Conn, R.S., Davis, P., Grenda, V.J., Zambito, A.J. Grabowski, J. Synthesis of (R)-serine-2-d and its conversion to the broad-spectrum antibiotic fludalanine, Org. Chem. 1987, 52, 33263334. https://doi.org/10.1021/jo00391a029.

[34] Saravanan, P., Corey, E.J. A Short, Stereocontrolled, and Practical Synthesis of $\alpha$-Methylomuralide, a Potent Inhibitor of Proteasome Function. J. Org. Chem.,2003, 68,2760-2764. https://doi.org/10.1021/jo0268916.

[35] Mrkus, L., Batinić, J., Bjelis, N., Jakas, R. Synthesis and biological evaluation of quercetin and resveratrol peptidyl derivatives as potential anticancer and antioxidant agents, AminoAcids., 2018, https://doi.org/10.1007/s00726-018-2668-6.

[36] Golshadi Ghalehshahi, H., Balalaie, S., Aliahmadi, A., Moghimi, R. Synthesis of 4-N- $\alpha$-coumaryl amino acids and investigation of their antioxidant, antimicrobial activities and fluorescence spectra, AminoAcids., 2018, https://doi.org/10.1007/s00726-018-2624-5.

[37] Steglich, W., Kober, R. Untersuchungen zur Reaktion von Acylaminobrommalonestern und Acylaminobromessigestern mit Trialkylphosphiten-eine einfache Synthese von 2-Amino-2(diethoxyphosphoryl)Essigsäure Ethylester. Liebig. Ann Chem. 1983, 4, 599-609. https://doi.org/10.1002/jlac.198319830409.

[38] Achamlale, S., Elachqar, A., El Hallaoui, A., El Hajji, S., Roumestant, M.L. Ph. Viallefont, Synthesis of $\alpha$ - triazolyl $\alpha$-amino acid derivatives. Amino Acids., $\quad 1997, \quad 12, \quad$ 257-263. https://doi.org/10.1007/BF01373006.

[39] Achamlale, S., Elachqar, A., El Hallaoui, A., El Hajji, S., Alami, A. Roumestant, M.L. Ph. Viallefont, Synthesis of biheterocyclic $\alpha$-amino acid. Amino Acids., 1999, 17, 149-163. https://doi.org/10.1007/BF01361878.

[40] Karai, O., Aouine, Y., Faraj, H., Alami, A., El Hallaoui, A., Zouihri, H. Methyl (2R)-2-benzamido-2-\{[(1R)-2-meth-oxy-2-oxo-1 phenyl-ethyl]amino -acetate, IUCrData.,2017,2, x171155. https://doi.org/10.1107/S2414314617011555.

[41] Karai, O., Aouine, Y., Faraj, H., Alami, A., El Hallaoui, A., Zouihri, H. Methyl (1-benzamido-2-methoxy-2-oxoethyl)-Tryptophanate IUCrData.,2017, https://doi.org/10.1107/S2414314617015474

[42] Rice-Evans C.A., Miller N.J., Bolwell P.G., Bramley P.M., Pridham J.B. "The relative antioxidant activities of plant-derived polyphenolic flavonoids", Free Radical Research, vol. 22, pp 375-383, 1995.https://doi.org/10.3109/10715769509145649.

[43] Bartosz G. Generation of reactive oxygen species in biological systems, Comments on Toxicology", vol. 9, pp5-21, 2003 https://doi.org/10.1080/08865140302420.

[44] Miller N.J., Rice-Evans C.A., Davies M.J., Gopinatan V. \& Milner A. A nouvel method for measuring antioxidant capacity and its application to monitoring antioxidant status in premature neonates. Clinic Science., 1993, 84: 407-412. https://doi.org/10.1042/cs0840407.

[45] Meister A., Bernhardt G., Christoffel V., Buschauer A. Antispasmodic activity of Thymus vulgaris extract on the isolated guinea-pig trachea: discrimination between drug and ethanol effects. Planta Medica. 1999, 65: 512-516. DOI: $10.1055 / \mathrm{s}-1999-14006$.

[46] Miquel-Becker E., Niessen L.R. \& Skibsted L.H. Antioxidan evaluation protocols:foods quality or health effects. Food Research and Technology., 2004,219: 561-571. https://doi.org/10.1007/s00217-004$1012-4$.
[47] Rivero-Pérez MD., Muniz P., Gonzalez-Sanjosé ML. Antioxidan profile of red wines evaluated by total antioxidant capacity, scavenger activity, and biomarkers of oxidative stress methodologies. J. Agric. Food Chem. 2007, 11: 5476-5483. https://doi.org/10.1021/jf070306q.

[48] Benzie I.F.F., and Strain J.J. The ferric reducing ability of plasma (FRAP) as a measure of "antioxidant power": The FRAP assay. Analytical Biochemistry., 1996. 239 (1): 70-76. https://doi.org/10.1006/abio.1996.0292.

[49] Portes E. Synthèse et Etudes de étrahydrocurcuminoïdes : Propriétés photochimiques et antioxydantes, applications à la préservation de matériaux d'origine naturelle., 2008. Thèse de doctorat. № $\gamma 695$. Université Bordeaux I. $\beta 44 \mathrm{p}$

[50] Hussain A.I. Characterization and biological activities of essential oils of some species of lamiaceae., 2009. Doctorale thesis, Pakistan. 257.

[51] Moon J-K., and Shibamoto TAntioxidant Assays for Plant and Food Components. J.Agric. Food Chem., 2009. 57 (5): 1655-1666. https://doi.org/10.1021/jf803537k.

[52] Castro L., Freeman B.A. Reactive oxygen species in human health and disease. Nutrition., 2001. Vol 17, Num 2, pp 161-165; ref: 43.

[53] Siddhuraju P., Becker K. The antioxidant and free radical scavenging activities of processed cowpea (Vigna unguiculata (L.) Walp) seed $\begin{array}{llll}\text { extracts. } & \text { Food } & \text { Chem., } & \text { 1007. }\end{array}$ https://doi.org/10.1016/j.foodchem.2006.01.004.

[54] Sanchez-Moreno, C. Methods used to evaluate the free radical scavenging activity infoods and biological systems. Int. J. of FoodsSci., 2002, Tech. 8: 121-137. https://doi.org/10.1106/108201302026770.

[55] Yang, J., Guo,J. J., Yuan. In vitro antioxidant properties of rutin LWT.,2008, 41, $\quad$ pp., $1060-1066$. https://doi.org/10.1016/j.lwt.2007.06.010.

[56] Karai, O., Aouine, Y., Faraj, H., Alami, A/, Kabbour, R.K., El Hallaoui, A., and Mohammed Bouksaim, M. Synthesis, characterization and antibacterial activity of Methyl (2R)-2-benzamido-2-\{[(1R)-2 methoxy-2-oxo-1-phenylethyl]amino \}acetate Mediterranean Journal of Chemistry 2018, 7(4), 267-271, http://dx.doi.org/10.13171/mjc74181110-alami.

[57] Karai, O.; El Hamdani, M.; Faraj, H.; Alami, A.; Kabbour, M.R.; E Hallaoui, A.; Bouksaim, M.; Aouine, Y. Methyl N-[1-(Benzoylamino)2-methoxy-2-oxoethyl]-tryptophanate. Molbank 2017, 2017, M958. https://doi.org/10.3390/M958.

[58] Karai, O., Aouine, Y., Faraj, H., Alami, A/, Kabbour, R.K., El Hallaoui, A., and Mohammed Bouksaim, M. Synthesis, characterization and antibacterial activity of Methyl (2R)-2-benzamido-2-\{[(1R)-2 methoxy-2-oxo-1-phenylethyl]amino $\}$ acetate Mediterranean Journal of Chemistry 2018, 7(4), 267-271, http://dx.doi.org/10.13171/mjc74181110-alami.

[59] Huang, D., Ouand, B., Prior, R.L. The chemistry behind antioxidant capacity assays. Jofagr Food chem., 2005.53:1841-1856 https://doi.org/10.1021/jf030723c.

[60] Benzie, I.F.F., Strain, J.J. The Ferric Reducing Ability of Plasma (FRAP) as a Measure of "Antioxidant Power": The FRAP Assay. Analytical Biochemistry., 1996, 239 (1): 70-76. https://doi.org/10.1006/abio.1996.0292.

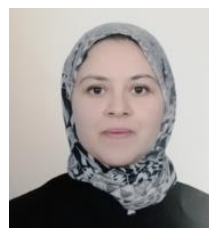

Oumaima Karai was born in Fez, Morocco, in 1990. She obtained her Bachelor's and master's degree in chemistry at Sidi Mohammed Ben Abdellah University Faculty of Sciences and technologies, Fez, Morocco, in 2011 and 2013. she is a doctor in organic chemistry since 2020 from Sidi Mohammed Ben Abdellah University Faculty of Sciences Dhar El Mahraz, Fez, Morocco. Her research interests include Synthesis and spectroscopic study of new compounds derived from heterocyclic and nonheterocyclic carboxylic $\alpha, \alpha$-diaminodiesters, and on the study of their biological and antioxidant activities. Her research has been the subject of several publications (indexed journals, and conferences).

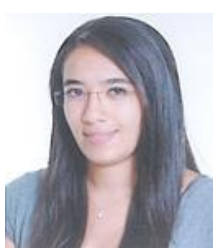

Sara Hajib was born in February 1990 in Fez, Morocco, where she completed her primary, secondary and university education.

The latter were capped respectively by obtaining a Bachelor's in chemical analysis techniques and quality control and a Master's degree in the chemistry of bioactive molecules at the Faculty of Sciences and Technologies of Fez in 2015.

Currently, she is pursuing for her Ph.D. degree at Sidi Mohammed Ben Abdellah University Faculty of Sciences Dhar El Mahraz, Fez, Morocco. 


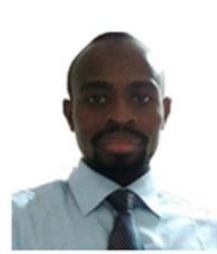

Serigne Abdou Khadir Fall was born in Bambey, Senegal, on $07 / 31 / 1988$. He is a PhD student in organic chemistry at the Faculty of Sciences, Dhar El Mahraz - Fez, Morroco. His research focused on the synthesis and study of bioactive molecules. Indeed, after obtaining his baccalaureate in 2009, he continued his studies in chemistry where he holds a bachelor's degree in industrial analytical chemistry in 2013, followed by a Master in the analytical chemistry of environmental technologies in 2015.

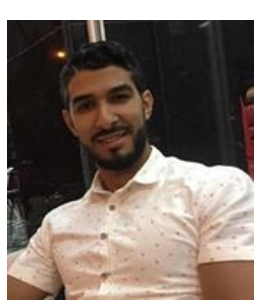

Salaheddine Boukhssas was born in Fez, Morocco, in 1992. He received his higher education degree in Chemistry and a Master's Degree in Organic Chemistry from Sidi Mohamed Ben Abdellah University, Faculty of Sciences DM of Fez, Morocco, respectively in 2014 and 2016. Then, he started a Ph.D. degree in the field of heterocyclic chemistry in the organic chemistry laboratory and he began his career as an assistant teacher in the same Faculty. In 2019, He has engaged in the field of education as a professor of Physical Sciences and Chemistry at Jbabra High school in Taounate City, Morocco.

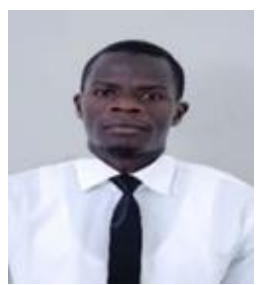

Khadim Dioukhane was born in Senegal where he obtained his baccalaureate degree in 2010 before coming to Morocco for university studies. He obtained his License in "Technology Food" at the Faculty of Sciences and Technologies of Sultan Moulay Slimane University of Béni Mellal, Morocco, in 2013. He obtained his Master degree in Structural Chemistry from the Faculty of Sciences of Sidi Mohamed Ben Abdellah University in Fez, Morocco, in 2015. Currently, he is pursuing for his doctoral studies in organic chemistry at the same faculty, where he focused on the synthesis, characterization, electrochemical and biological studies of certain mono and biheterocyclic compounds.

https://orcid.org/0000-0001-5275-6131

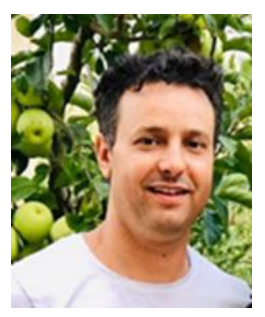

Younas Aouine was born in Ait-Seghrouchen of Taza, Morocco, in 1979. He received his higher education diploma in Chemistry from the Sidi Mohamed Ben Abdellah University of Fez, Morocco, in 2003. He obtained his advanced degree (D.E.S.A) and Ph.D. degree in Organic and Heterocyclic Chemistry from the same university, in 2005 and 2015, respectively. Since 2006, he has been working as a researcher in organic chemistry laboratory (LCO) with Professors at Faculty of Sciences DM, University of Fez. In 2008, he joined the Ministry of Education as a professor of Physical Sciences and Chemistry in Imzouren High School, Al Hoceima in northern Morocco. Since 2018, he joined the Department of Chemistry of the Ibn Zohr University, Agadir, as an assistant professor. His teaching has been devoted to organic and heterocyclic chemistry courses. His current research is focalized firstly on synthesis and characterization of new heterocyclic $\alpha$-amino acids and their precursors and on the other hand on the study of their biological and electrochemical activities. He has published the results of research ( +70 publications and communications) in several international journals.

https://orcid.org/0000-0001-7691-5598.

Scopus Author ID: 35742904200.

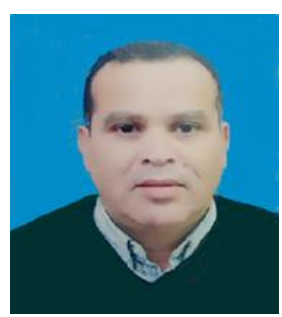

Brahim Labriti was born in Tiflet, Morocco, in 1962. He studied the Chemistry at the Faculty of Sciences Dhar El Mehraz, Sidi Mohammed Ben Abdellah University in Fez Morocco, where he obtained his Ph.D. degree in 1994. He then joined the department of chemistry at the same Faculty in 1996 as an assistant professor. He is a member of the amino acids and peptides team in the organic chemistry laboratory. His current research is concentrated on the synthesis and characterization of new tetrazolic $\alpha$ - amino acids and their precursors and on the study of their biological and electrochemical activities.

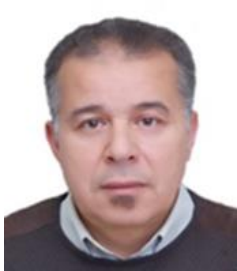

Faraj Hassane was born in Fez, Morocco, in 1963. He studied Chemistry at Montpellier II University, France and he obtained his Ph.D. degree in 1991. He then joined the department of chemistry at the Faculty of Sciences Dhar El Marhaz, Sidi Mohamed Ben Abdellah University (Fez, Morocco) in 1993.

His current research is focused on the synthesis and characterization of new heterocyclic $\alpha$-amino acids and their precursors and on the other hand on the study of their biological and electrochemical activities. He has taken part in conferences and communications in national and international congresses and has published the results of research (+70 publications and communications) in several international journals.

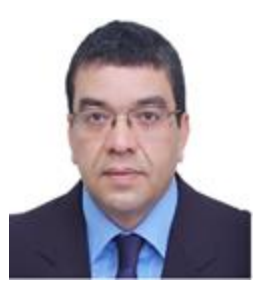

Anouar Alami was born in Fez, Morocco, in 1966. He studied Chemistry at Montpellier II University, France and he obtained his Ph.D. degree in 1991. He then joined the Department of Chemistry at the FSDM, USMBA Fez, Morocco in 1992. He prepared his state doctorate thesis degree in Organic Chemistry in 1997 at USMBA. Among the responsibilities he assumed: Head of Department of Chemistry, elected for two terms 2013-2015 and 2016-2017 of the Council of FSDM, Chairman of the Transmediterranean Colloquium on Heterocyclic Chemistry, November 22-25, 2017, Fez, Morocco, http://tramech9.raidghost.com/, Responsible for the doctoral training "Bioactive Molecules, Health and Biotechnologies", 2014-2018, Director of the Laboratory of organic chemistry, 2014-2018, Coordinator of the Bachelor's degree program "Chemistry Sciences", FSDM, 2005-2012, Project Manager "President of the Coordination Commission with higher education, from the Board of the Academy of Fez-Boulemane Region, 2009-2012, Elected Member of the Council of USMBA, Fez, 2009-2011, Elected member of the Management Board USMBA, Fez 2011, Chairman of the International Symposium on heterocyclic chemistry, October 26-29, 2011. http://ishc2011.6te.net/Sitefr/index.html, Elected member of the college of the chemistry department, 2000-2012.

He strongly believes in the cognitive complementarity of science and in parallel to all his responsibilities, he had prepared a DEUG (2008) and a License (2010) in Private Law in French and a Master in Economics and Management (2013) at the Faculty of Economics, Law, and Social Sciences of Fez. Concerning the scientific research side. He had published more than 140 scientific publications indexed in several databases (Scopus, Web of science, Elsevier, Eric, IMIST...), in various fields: Heterocyclic chemistry, molecular biology, science education, applied research in pedagogy, Educational Technology)

ORCID ID: https://orcid.org/0000-0002-3951-9382.

Scopus Author ID: 6603718514.

Web of Science Researcher ID: T-6219-2019. 